\title{
Optimization of the method for isolation of epithelial cells from the non- glandular part of the rat stomach for flow cytometry
}

\author{
Gordana Joksić ${ }^{1 *}$, Jelena Filipović Tričković1, Mileva Mićićé, Ivana Joksić1,3, \\ Ana Valenta Šobot ${ }^{1}$, and Miroslav Demajo ${ }^{1}$ \\ ${ }^{1}$, VINČA” Institute of Nuclear Sciences - National Institute of the Republic of Serbia, University of Belgrade, \\ Begrade, Republic of Serbia \\ ${ }_{2}^{2}$ Institute for Medical Research, University of Belgrade, Belgrade, Republic of Serbia \\ ${ }^{3}$ Clinic for Gynecology and Obstetrics Narodni Front, Belgrade, Republic of Serbia
}

JOKSIĆ, G., J. FILIPOVIĆ TRIČKOVIĆ, M. MIĆIĆ, I. JOKSIĆ, A. VALENTA ŠOBOT, M. DEMAJO: Optimization of the method for isolation of epithelial cells from the non-glandular part of the rat stomach for flow cytometry. Vet. arhiv 90, 517-525, 2020.

\section{ABSTRACT}

Traditional methods in cell proliferation studies are based on immunohistochemical detection of proliferating cells in the target tissue. Since they are time consuming, optimization of novel, more efficient methods is important for large scale proliferation studies. In this study, we aimed to optimize the isolation of single epithelial rat forestomach cells for flow cytometry. As a marker of cellular proliferation we used the Ki-67 antibody to detect this nuclear protein expressed in proliferating cells. We also performed immunohistochemical detection of Ki-67 positive cells and propidium iodide staining to validate the results. 3-tert- butyl -4-hydroxyanisole was used as the positive control to ensure cellular proliferation. The results showed that isolation of epithelial cells with collagenase, trypsin and cell strainer ensures great cell viability ( $>95 \%$ ) and the purity of the samples. Flow cytometry and immunostaining with the Ki-67 antibody indicated that 3-tert- butyl-4-hydroxyanisole treatment leads to a significant increase in proliferation. A significant positive correlation was observed between the results obtained by immunohistochemistry and flow cytometry, but the flow cytometric data had a smaller measurement error, suggesting the equal sensitivity and greater accuracy of this method. Propidium iodide staining showed that the percentage of cells in the $\mathrm{G} 2+\mathrm{S}$ phase of the cell cycle correlated positively with the percentage of Ki-67 positive cells assessed by flow cytometry, indicating that Ki-67 positive cells reflect an active dividing cell pool. We conclude that the isolation of forestomach epithelial cells described is a simple and reliable method for obtaining viable cells for use in flow cytometry. Compared to immunohistochemistry, flow cytometric detection of the Ki-67 antigen is equally sensitive, but much faster and provides more accurate results.

Key words: Ki-67; epithelial cell isolation; flow cytometry; non-glandular part of the rat stomach; cell proliferation

\section{Introduction}

The rat's stomach consists of two histologically and physiologically different parts, separated by a mucosal fold called the limiting ridge: the proximal non-glandular part - the forestomach,

and the distal glandular part, which has secretory and digestive functions. The forestomach is lined by a keratinized stratified squamous epithelium and its main function is to serve as a storage organ.

*Corresponding author:

Gordana Joksić, PhD, Vinča Institute of Nuclear Sciences, University of Belgrade, Mike Petrovića Alasa 12-14, Belgrade, Serbia, Phone: +381 11 340 8565; E-mail: gjoksic@vin.bg.ac.rs 
Prolonged contact with ingested food makes it a model system for investigation of the in vivo effects (genotoxic or non-genotoxic) of various xenobiotics administered per os (GREAVES, 2012; UEHARA et al., 2018). The observed effects may be applied to the human esophagus, pharynx and oral cavity, due to their similarity in terms of the histopathological characteristics of the mucosal layer (PROCTOR et al., 2007).

Traditional methods for determination of proliferative changes in the rat forestomach mostly rely on immunohistochemical (IHC) procedures to detect different markers of cellular proliferation, such as 5-bromo-2'-deoxyuridine (BrdU) or the Ki67 nuclear antigen (JOKSIĆ et al., 2017; TANAKA et al., 2011; KING et al., 1982). Our previous investigation demonstrated that subcutaneous implementation of BrdU matrices led to the slow release of BrdU, which incorporated into the newly synthesized DNA molecule during the $\mathrm{S}$ phase of the cell cycle (JOKSIĆ et al., 2017), enabling accurate identification of dividing cells. Unlike BrdU, Ki67 is a nuclear antigen expressed in the G1, S, G2 and $\mathrm{M}$ phases of the cell cycle, but is not expressed in the resting (G0 phase) or differentiated cells, so it provides information about the proliferative state (NAKAJIMA et al., 1999). Comparison between BrdU and Ki-67 dual immunostaining revealed a strong correlation $(\mathrm{P}<0.01)$ between these two markers in different tissues (MUSKHELISHVILI et al., 2003).

Even though IHC represents the gold standard for assessment of cellular proliferation, it is timeconsuming since sample preparation and analysis require a significant amount of time. Thus, implementation and optimization of novel methods are of great importance, especially in toxicological studies where quick evaluation may be required. A simple and reliable alternative in cell proliferation studies is flow cytometry, since a large number of samples can be quantitatively analyzed at the same time (POZAROWSKI and DARZYNKIEWICZ, 2004). However, flow cytometry requires optimization of a method for preparation of single cell suspensions. In the case of the gastrointestinal tract, numerous studies have reported isolation of single gut cells from different species, including rats (BOCKERSTETT et al., 2018; TRAN and FERRERO, 2018; QIN and PEI, 2018; SMITH et al., 2008), but, to the best of our knowledge, isolation of single cells from the stratified squamous epithelium of the rat forestomach has not yet been reported. In this study, we established a protocol for isolation of a single cell suspension from the rat forestomach. As a proliferation agent we used the food antioxidant 3-tert- butyl-4-hydroxyanisole (BHA) (GREAVES, 2012; JOKSIĆ et al., 2017). For validation, we compared the results obtained by using three methods on the same samples: flow cytometry using propidium iodide (for the assessment of the cell cycle) and the Ki-67 monoclonal antibody, as well as IHC staining using the Ki-67 antibody on the forestomach tissue sections.

\section{Materials and methods}

Animals. A total of 8 animals were included in this study. All experimental procedures on animals were approved by the Ethical Committee for the Use of Laboratory Animals of the Vinča Institute of Nuclear Sciences, according to the guidelines of the EU registered Serbian Laboratory Animal Science Association, OECD good laboratory practice rules and Directive 2010/63/EU (Number of Ethical Committee approval 232-07-08900/2016-05, date of approval 06.10.2016.). Seven week old male Wistar rats $(327 \pm 26 \mathrm{~g})$, from separate litters, obtained from a local colony, were maintained under standard conditions: group-housed (4 per cage) with ad libitum access to food (commercial pellet) and tap water, a regular $12 \mathrm{~h}$ light/12 h dark cycle, and constant humidity and temperature (21 $\left.\pm 2^{\circ} \mathrm{C}\right)$.

Treatment and surgical procedure. Depending on the experimental treatment, the animals were divided into two groups: an untreated control group $(n=4)$ and a group of animals treated with BHA (Sigma-Aldrich Co., Saint Louis, Missouri, USA) $(n=4)$, which served as a positive control. BHA, 2\% in powdered feed, was administered intragastrically by intubation using a stainless steel reuptake needle (16-G4, $3 \mathrm{~mm}$ diameter, Cadence Inc., Staunton, Virginia, USA) three times a week for 6 weeks (JOKSIĆ et al., 2017). 
Tissue preparation. Prior to sacrifice, the animals were anesthetised with $5 \%$ chloral hydrate (400 mg/kg, Sigma-Aldrich Co., St. Louis, USA). Sacrifice was performed by decapitation, the stomachs were removed, forestomachs separated, cut along the minor curvature and washed in $0.9 \%$ aqueous sodium chloride. Approximately $10 \%$ of the forestomach tissue was used for IHC, whereas the remaining tissue was transferred to sterile tubes containing HBSS medium (Hank's Balanced Salt Solution, GIBCO ${ }^{\circledR}$, Thermo Fisher Scientific) for isolation of single epithelial cells.

Ki-67 immunohistochemistry. For IHC analysis, forestomachs were fixed in $10 \%$ neutral buffered formalin for one week. After fixation, the tissue was processed through a series of alcohols, embedded into paraffin blocks, and cut transversely into serial sections of $4 \mu \mathrm{m}$ thickness. Ten consecutive sections in duplicate, ranged $250 \mu \mathrm{m}$ between each other, were taken for hematoxylin and eosin (H\&E) staining (a) and IHC staining for detection of the Ki-67 nuclear antigen (b).

The Ki-67 monoclonal antibody (SolA15 conjugated with Biotin, eBioscience ${ }^{\mathrm{TM}}$ ) was used for IHC staining (final concentration $5 \mu \mathrm{g} /$ $\mathrm{mL}$ ), Avidin-HRP as the detection system (ABC Peroxidase Standard Staining Kit, Thermo Scientific ${ }^{\mathrm{TM}}$ ), and 3,3'-diaminobenzidine (DAB) was used as the chromogen for visualization (Pierce ${ }^{\mathrm{TM}} \mathrm{DAB}$ Substrate Kit). Tissue sections incubated with normal serum instead of the primary antiserum were used for the control staining. The sections were counterstained with Mayer's hematoxylin (Merck, Billerica, MA, USA) for analysis under the light microscope. The analysis was performed on an Olympus AX70 light microscope with $10 \times$ and $20 \times$ lens magnification. The results are presented as the proliferation index (PI) calculated as the ratio between the immunoreactive cells (dividing cells, $\mathrm{Ki}-67^{+}$cells) and the total number of cells per $\mathrm{mm}^{2}$. At least 10 tissue sections per animal were counted, and the PI was expressed as a percentage.

Isolation of single cells from tissue. The tissue used for isolation of single epithelial cells from the forestomach was placed in HBSS medium, cut into small pieces, resuspended and allowed to settle. The supernatant was discarded; $2 \mathrm{~mL}$ of collagenase, Type IV (200 U/mL, GIBCO ${ }^{\circledR}$, Thermo Fisher Scientific) per test tube was added, and incubated at $37{ }^{\circ} \mathrm{C}$ for $1 \mathrm{~h}$. Single cell suspensions were prepared by grinding the tissue between the frosted ends of microscopic glass slides in HBSS medium (preheated to $37{ }^{\circ} \mathrm{C}$ ). The cells were collected in tubes and centrifuged for 5 minutes at $1200 \mathrm{rpm}$ (rotations per minute). After discharge of the supernatant, the cells were washed one more time in HBSS and supplemented with $1 \mathrm{~mL}$ of trypsin EDTA in HBSS (0.5 g/L, Irvin Scientific, USA). Following incubation of the cells in trypsin EDTA for 30 minutes at $37^{\circ} \mathrm{C}, 2 \mathrm{~mL}$ of Dulbecco's Modified Eagle's Medium (DMEM), supplemented with 10\% Fetal Bovine Serum (FBS, Capricorn Scientific, Germany), was added to inhibit trypsin activity. The cells were gently resuspended and filtered through a cell strainer (Sarstedt, pore size $40 \mu \mathrm{m})$. The collected pellet was washed twice in PBS ( $\mathrm{pH}=7.4)$, and fixed in $100 \%$ ice cold ethanol drop wise while vortexing. Prior to fixation, the cells were counted in a standard haemocytometer, and viability was assessed by the Trypan Blue exclusion test, and the cell viability was determined to be greater than $95 \%$.

Flow Cytometry using Ki-67 monoclonal antibody. Direct labelling of single epithelial cells from the rat forestomach was performed by incubating $1 \pm 0.5 \times 10^{6}$ cells for 30 minutes at room temperature in the dark, with fluorescein isothiocyanate (FITC) conjugated Ki-67 monoclonal antibody (eBioscience ${ }^{\mathrm{TM}}$ ) or the appropriate isotypic control (Rat IgG2a kappa Isotype Control (eBR2a), FITC, eBioscience ${ }^{\mathrm{TM}}$ ), to a final concentration of $5 \mu \mathrm{g} / \mathrm{mL}$. Afterwards, the pellet was washed three times with PBS, and analyzed using a BD FACSCalibur ${ }^{\mathrm{TM}}$ flow cytometer (Becton Dickinson, USA). Cell concentrations of $5 \times 10^{4}$ were analyzed. Forward light scatter gates were set to exclude dead cells and debris. The analysis was performed in relation to the corresponding isotype control, using FAC Express V6 software for analysis of data obtained from the flow cytometer.

Flow cytometry for assessment of DNA content and cell cycle using propidium iodide. The same amount of cells used for Ki-67 labeling was used 
for DNA cell cycle analysis. Cells fixed in $100 \%$ ice cold ethanol $\left(-20{ }^{\circ} \mathrm{C}\right)$ overnight were centrifuged at $1200 \mathrm{rpm}$, the supernatant was discarded and the pellet was washed twice in PBS. The supernatant was aspirated, and the cells were incubated in a water bath at $37^{\circ} \mathrm{C}$ for 30 minutes, in the presence of $0.5 \mathrm{~mL}$ RNase solution (final concentration $1 \mathrm{mg} /$ $\mathrm{mL}$, Serva, Germany). Following this treatment, 0.5 $\mathrm{mL}$ of propidium iodide (final concentration $40 \mu \mathrm{g}$ / mL, Sigma-Aldrich Co., Saint Louis, Missouri, USA) was added to each sample, and the samples were incubated for 10 minutes at room temperature protected from light. Analyses were performed by FAC using the DNA Cell-cycle software program.

Statistical analysis. The obtained data were analysed using computer software SPSS 10 for Windows (IBM, USA). The results were expressed as the mean value \pm SEM. The values were compared using the non-parametric Mann-Whitney $\mathrm{U}$ test, and $\mathrm{P}<0.05$ was accepted as the level of significance. The Pearson correlation coefficient was used to compare the results obtained by immunohistochemistry and flow cytometry from the same samples.

\section{Results}

Proliferation marker Ki-67 expression in the forestomach of rats - immunohistochemistry. Proliferation marker Ki-67 expression in the rat forestomach is visible in the cells of the basal layer of the stratified squamous epithelium. The proliferation index (PI) was calculated as the ratio of $\mathrm{Ki}-67^{+}$cells to the total number of cell counts (Ki-67 ${ }^{+}$and $\mathrm{Ki}-67^{-}$) per $\mathrm{mm}^{2}$ (Table 1). PI in

A
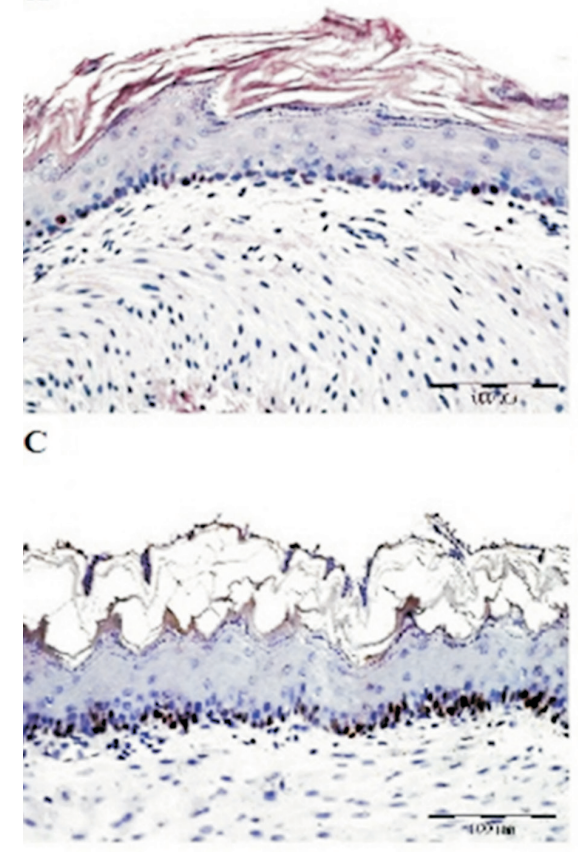

BHA treated animals was $35.11 \pm 0.1$, which was statistically significantly higher compared to the control animals, $21.36 \pm 0.66(\mathrm{P}<0.001$, Table 1 , Fig. 1).

Cell proliferation examined by flow cytometer. Different dyes are available to monitor proliferation throughout the cell cycle stages, by measuring the DNA content in cells, and they all have a high DNA binding affinity.
B

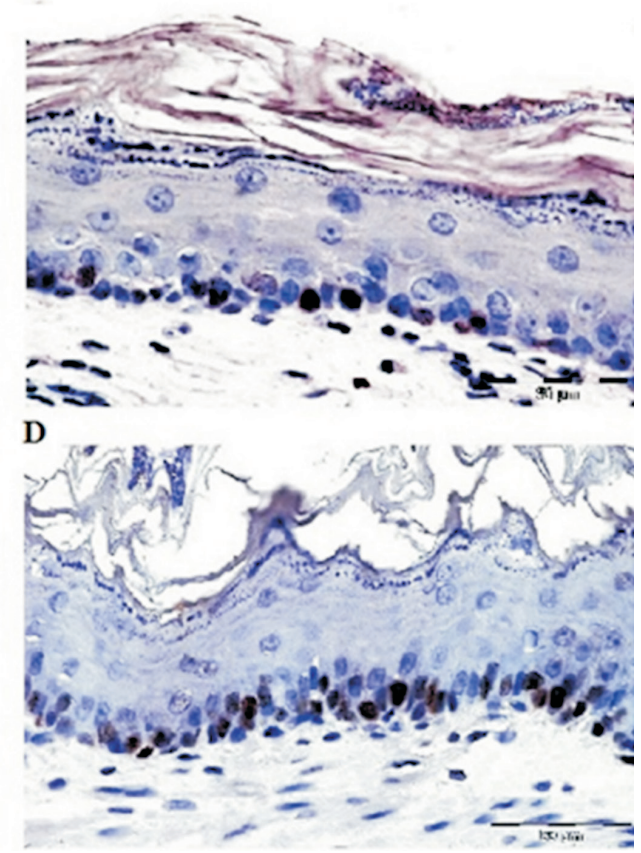

Fig. 1. Photomicrographs of immunohistochemical staining of the rat forestomach with Ki-67 antibody, control

$(\mathrm{A}, \mathrm{B})$ and BHA, treated for six weeks $(\mathrm{C}, \mathrm{D})$. Brown labeled cells represent $\mathrm{Ki}-67^{+}$cells. A higher number of immunoreactive cells can be seen in BHA treated rats. Magnification 20x, scale bar $100 \mu \mathrm{m}(\mathrm{A}, \mathrm{C})$ and 40x, scale bar $50 \mu \mathrm{m}(\mathrm{B}, \mathrm{D})$. 
Table 1. Proliferation index (\%) assessed by immunostaining in the forestomach of control and BHA treated animals

\begin{tabular}{|c|c|c|}
\hline & Control & BHA treated group \\
\hline Proliferation index & $21.36 \pm 0.66$ & $35.11 \pm 0.1^{*}$ \\
\hline
\end{tabular}

* $\mathrm{P}<0.001$ control vs. BHA treated group. Results are presented as Mean \pm SEM.

Propidium Iodide. During the analysis of single cell suspensions from the forestomach epithelium, we first identified cells on the forward (FSC) and side scatter (SSC) plots, then live cells were gated (Fig. 2) to exclude apoptotic cells and cell doublets, i.e. only live cells were used to analyze the cell distribution according to the cell cycle on histograms.

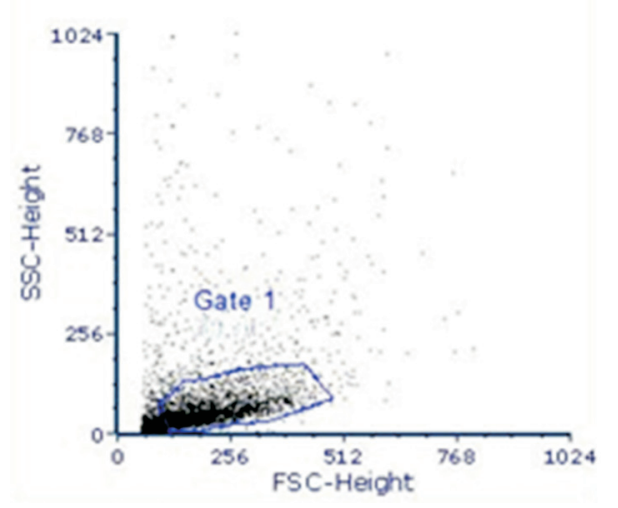

Fig. 2. Dot plots of forestomach cells within forward and side scatter. Live cells are distributed within Gate 1.

The DNA histogram shows the ratio of cells at different stages of the cell cycle. In the control animals, the largest percentage of cells analyzed was in the G1 phase of the cell cycle, $12.27 \pm 0.3$.
In the animals treated with BHA, the percentage of cells in the G1 phase of the cell cycle was similar to that in the control rats, $12.13 \pm 0.8$, whereas the percentage of cells in the $\mathrm{S}+\mathrm{G} 2$ phase of the cell cycle was higher compared to the control animals, $16.56 \pm 0.46$ vs. $9.38 \pm 0.99$, respectively $(\mathrm{P}<0.05)$ (Fig. 3).

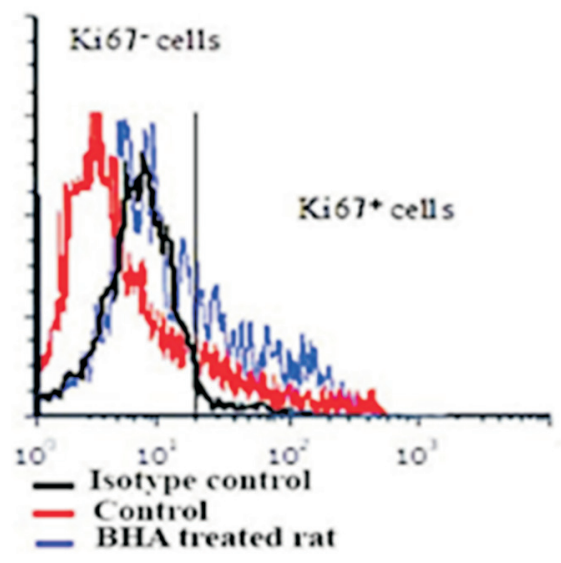

Fig. 4. Histograms of the total pool of Ki- $67^{-}$and $\mathrm{Ki}-67^{+}$ cells in the control and BHA treated animals, and the relationship with isotype control.

$\mathrm{Ki}-67$. Since Ki-67 ${ }^{-}$and $\mathrm{Ki}-67^{+}$cells overlap, a negative (isotype) control (Fig. 4) was used in these studies to evaluate the population of $\mathrm{Ki}-67^{+}$cells. Comparison of the $\mathrm{Ki}-67^{+}$cell counts in the control and treated rats showed a significant increase in the $\mathrm{Ki}-67^{+}$cell count in the BHA treated animals $(\mathrm{P}<0.05)$ (Fig. 5). It was shown that the percentage of $\mathrm{Ki}-67^{+}$cells was $20.67 \pm 1.5$ in the control animals, while in animals treated with BHA the percentage was significantly higher, at $31.2 \pm 1.04$ (Table 2).
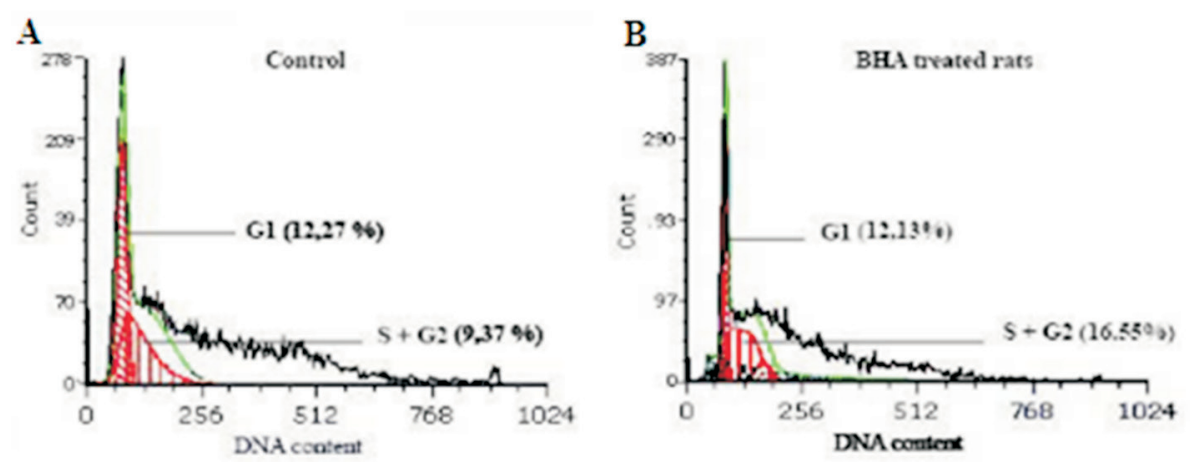

Fig. 3. Histogram of forestomach cells stained for DNA content using propidium iodide. A higher percentage of cells in the $\mathrm{S}+\mathrm{G} 2$ phase of the cell cycle in BHA treated rats can be observed. Control (A) and BHA treated rats (B). 

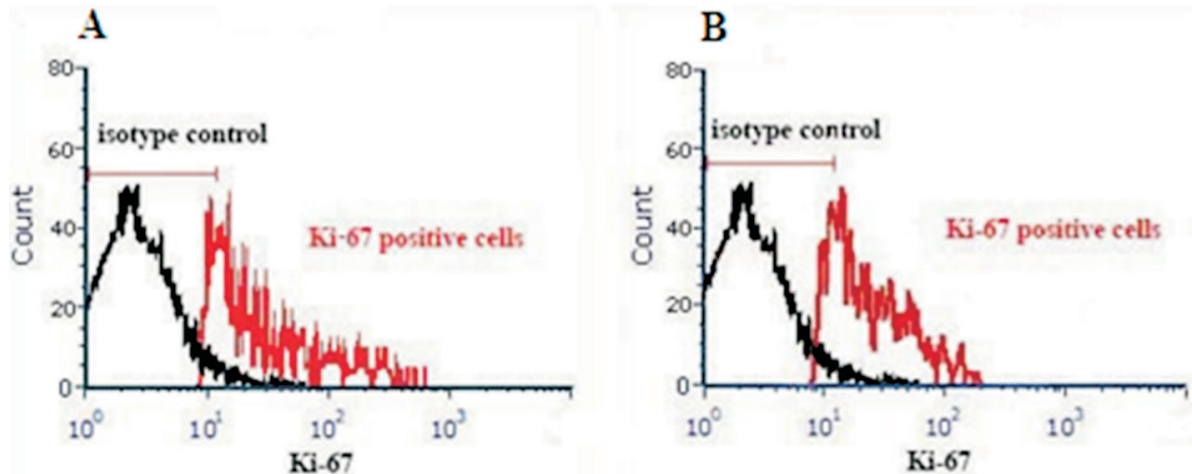

Fig. 5. Histograms of only Ki- $67^{+}$cells in the forestomach of control rats (A) and BHA-treated rats (B), and their relationship with the isotype control.

Table 2. Percentage of Ki-67 ${ }^{+}$and Ki-67- cells in control and BHA treated rats assessed by flow cytometry

\begin{tabular}{|l|c|c|}
\hline Groups & Ki-67 ${ }^{+}$cells & Ki-67 cells \\
\hline Control & $20.67 \pm 1.5$ & $79.33 \pm 1.5$ \\
\hline BHA treated rats & $31.2 \pm 1.04^{*}$ & $68.8 \pm 1.04$ \\
\hline
\end{tabular}

** $\mathrm{P}<0.05$, control $v s$. BHA treated group. Results are presented as Mean \pm SEM.

Methods comparison. After analysis of the data obtained by using different methods, we correlated the results to evaluate the reliability of the data acquired by flow cytometry. Pearsons' bivariate analysis showed that there was a statistically significant positive correlation between PI assessed by immunohistochemistry and the percentage of Ki- $67^{+}$cells assessed by flow cytometry $(\mathrm{P}<0.05$, $\mathrm{r}=0.784)$ in both the control and the BHA treated samples. Furthermore, significant positive correlations were observed between PI and the percentage of cells in the $\mathrm{G} 2+\mathrm{S}$ phase of the cell cycle $(\mathrm{P}<0.05, \mathrm{r}=0.821)$, as well as between the $\mathrm{Ki}-67^{+}$cells and the percentage of cells in the $\mathrm{G} 2+\mathrm{S}$ phase $(\mathrm{P}<0.01, \mathrm{r}=0.94)$.

\section{Discussion}

In this study we aimed to optimize the method for isolation and labeling of single cells from the stratified squamous epithelium of the rat forestomach, for evaluation in cell proliferation studies. To ensure cellular proliferation we used BHA, a widely used non-genotoxic food antioxidant. Previous studies have demonstrated that not only prolonged exposure to BHA induces inflammation followed by squamous hyperplasia, but also a dietary regime as short as one week with exposure to $2 \%$ BHA leads to epithelial hyperplasia along the minor curvature (ALTMANN et al., 1985; ITO et al., 1983). Our previous study demonstrated that intragastrical intubation of rats with $2 \%$ BHA in powdered feed for 6 weeks led to increased epithelial proliferation as assessed by $\mathrm{BrdU}$ proliferation assay; hence we used this treatment to ensure cellular proliferation (JOKSIĆ et al., 2019; JOKSIĆ et al., 2017; NILSSON et al., 2016). Given the complexity of BrdU proliferation assay for performing in vivo studies, including subcutaneous or intraperitoneal administration of $\mathrm{BrdU}$, the necessity arises to measure different endogenously expressed markers of cellular proliferation. Additionally, BrdU incorporates in the DNA during repair, so it might not be the right choice when it comes to toxicology studies. Among the tested endogenous markers for detection of proliferating cells, such as Proliferating Cell Nuclear Antigen (PCNA), histone mRNA and Ki-67, the latter showed the highest specificity and correlation with BrdU immunostaining (MUSKHELISHVILI et al., 2003). Since Ki-67 immunostaining strongly correlates with $\mathrm{BrdU}$, we performed Ki-67 IHC staining and analysis. Quantification of $\mathrm{Ki}-67^{+}$ epithelial cells in the rat forestomach demonstrated that BHA leads to a significant increase in the percentage of proliferating cells. Our previous research with BrdU immunostaining also showed a significant, but much higher increase in proliferation after 6 weeks of BHA treatment (JOKSIĆ et al., 2017). However, in that experiment, the BrdU 
matrices were subcutaneously implanted 3 days prior to the sacrifice of the animals, so BrdU was incorporated into the DNA of all the cells entering the $\mathrm{S}$ phase during that period of time. On the other hand, Ki-67 staining reflects the proliferative state at the moment of sacrifice (TANAKA et al., 2011).

In order to perform flow cytometric assessment of cellular proliferation, isolation of single viable cells from the forestomach tissue was performed. There are several papers describing the isolation of single cells from the glandular part of the rat stomach, jejunum or colon, relying predominantly on dispase treatment (DE FARIA et al., 2004; GRACZ et al., 2012; KEANE et al., 2015), but none of them focus on the forestomach tissue. The glandular stomach is comprised of histologicaly different epithelium (simple columnar mucous epithelium), so the procedure for obtaining single cells from the forestomach should be adjusted and optimized for the keratinized stratified squamous epithelium. Our approach to isolation of single cells was based on the following principles (REICHARD and ASOSINGH, 2019): maximizing the surface area between the tissue and enzymes, which we achieved by cutting the tissue before incubation with enzymes; enzymatic extracellular matrix digestion, for which we used collagenase type IV; cleaving cell-cell junctions with trypsin EDTA, and finally removing debris and undigested tissue aggregates by filtration through a cell strainer. This approach ensured great cell viability ( $>95 \%$ assessed by trypan blue exclusion test) and the purity of the samples. The results of flow cytometry with the Ki-67 antibody on these cells showed a statistically significant increase in PI in animals treated with BHA, compared to untreated animals. A comparison of the results obtained by IHC and flow cytometry showed a statistically significant correlation between these two methods, i.e. in the control samples the mean PIs reached 21.36 and $20.67 \%$, respectively, whilst in the BHA treated animals they accounted for 35.2 and $31.2 \%$. These slightly higher PIs in the IHC evaluated samples might be due to the fact that even though IHC counting was performed on a large number of tissue sections (at least 10), the number of cells analyzed was limited. On the other hand, flow cytometric analyses was performed on the cells from the whole target tissue, so the data obtained have a smaller measurement error, i.e. the results are considered to be more accurate. Some previous studies also demonstrated a strong correlation between the two methods in human colorectal adenocarcinomas, breast carcinomas and immunoproliferative diseases, suggesting the high reliability of this assay (LI et al., 2015; LE PESSOT et al., 2001; ISOLA et al., 1990). Since the Ki-67 protein is differentially expressed in the G1, S, G2 and $M$ phases of the cell cycle at different levels, we also performed propidium iodide staining. Previous research showed that Ki-67 levels increase during the cell cycle, with the lowest expression in G1, reaching the highest peak in the G2 phase and mitosis, thus reflecting the proliferative state of the cells (SOBECKI et al., 2017). In our research, propidium iodide staining showed that there was no significant difference in the number of cells in the G1 phase in the control and BHA treated animals $(12.27 \%$ vs. $12.13 \%$, respectively), while the percentage of cells in the $\mathrm{G} 2+\mathrm{S}$ phase was statistically significant higher in BHA treated rats $(\mathrm{P}<0.05$, Fig. 3). Moreover, the percentage of Ki$67^{+}$cells assessed by flow cytometry significantly correlated with percentage of cells in the G2+S phase of the cell cycle, suggesting that the elevated percentage of $\mathrm{Ki}-67^{+}$cells reflects actively dividing cells.

\section{Conclusions}

Our results demonstrate that isolation of forestomach epithelial cells is a simple and reliable method for obtaining a high percentage of viable cells that can be further used for other applications, such as flow cytometry. Flow cytometric detection of $\mathrm{Ki}-67^{+}$cells in forestomach tissue is much faster compared to traditional IHC detection, while it provides equally sensitive and consistent results. Overall, this methodological approach could be of great importance in large scale cell proliferation studies where rapid evaluation of proliferation is necessary.

\section{Acknowledgement}

This work was supported by the Ministry of Education, Science and Technological Development of the Republic of Serbia (Project No. 173046). 


\section{References}

ALTMANN, H. J., P. W. WESTER, G. MATTHIASCHK, W. GRUNOW, C. A. VAN DER HEIJDEN (1985): Induction of early lesions in the forestomach of rats by 3-tert-butyl-4hydroxyanisole (BHA). Food Chem. Toxicol. 23, 723-731. DOI: 10.1016/0278-6915(85)90265-0

BOCKERSTETT, K. A., C. F. WONG, S. KOEHM, E. L. FORD, R. J. DIPAOLO (2018): Molecular Characterization of Gastric Epithelial Cells Using Flow Cytometry. Int. J. Mol. Sci. 19, E1096.

DOI: $10.3390 /$ ijms 19041096

DE FARIA, W., P. TRYPHONOPOULOS, G. KLEINER, S. SANTIAGO, C. GANDIA, P. RUIZ, A. TZAKIS (2004): Study of the development and evolution of neointestine in a rat model. Transplant. Proc. 36, 375-376.

DOI: $10.1016 /$ j.transproceed.2004.01.085

GRACZ, A. D., B. J. PUTHOFF, S. T. MAGNESS (2012): Identification, isolation, and culture of intestinal epithelial stem cells from murine intestine. Methods Mol. Biol. 879, 89-107.

DOI: $10.1007 / 978-1-61779-815-3 \_6$

GREAVES, P (2012): Chapter 8 - Digestive System. In: Histopathology of Preclinical Toxicity Studies. (Greaves, P., Ed.), Academic Press, Boston, pp. 325-431.

ISOLA, J. J., H. J. HELIN, M. J. HELLE, O. P. KALLIONIEMI (1990): Evaluation of cell proliferation in breast carcinoma. Comparison of Ki-67 immunohistochemical study, DNA flow cytometric analysis, and mitotic count. Cancer 65, 1180-1184.

DOI: $10.1002 / 1097-0142(19900301) 65: 5<1180$ ::aidcncr2820650525>3.0.co;2-7

ITO, N., S. FUKUSHIMA, A. HAGIWARA, M. SHIBATA, T. OGISO (1983): Carcinogenicity of butylated hydroxyanisole in F344 rats. J. Natl. Cancer Inst. 70, 343-352. DOI: $10.1093 /$ jnci/70.2.343

JOKSIĆ, G., M. MIĆIĆ, J. FILIPOVIĆ, D. DRAKULIĆ, M. STANOJLOVIĆ, B. ČALIJA, A. VALENTA ŠOBOT, M. DEMAJO, R NILSSON (2017): Cell proliferation assay method optimisation for in vivo labeling of DNA in the rat forestomach. Acta Vet. (Belgr.), 67, 1-10.

DOI: $10.1515 /$ acve-2017-0001

JOKSIĆ, G., L. E. RUTQVIST, M. MIĆIĆ, J. F. TRIČKOVIĆ, R. NILSSON (2019): Factors effecting the induction of rat forestomach hyperplasia induced by Swedish oral smokeless tobacco (snus). Regul. Toxicol. Pharmacol. 104, 21-28.

DOI: 10.1016/j.yrtph.2019.02.015

KEANE, T. J., A. DEWARD, R. LONDONO, L. T. SALDIN, A. A. CASTleton, L. CAREY, A. NiEPONICE, E. LAGASSE, S. F. BADYLAK (2015): Tissue-Specific Effects of Esophageal Extracellular Matrix. Tissue Eng. Part A 21, 2293-2300.

DOI: $10.1089 /$ ten.tea.2015.0322
KING, M. T., D. WILD, E. GOCKE, K. ECKHARDT (1982): 5-Bromodeoxyuridine tablets with improved depot effect for analysis in vivo of sister-chromatid exchanges in bonemarrow and spermatogonial cells. Mutat. Res. 97, 117-129. DOI: 10.1016/0165-1161(82)90009-7

LE PESSOT, F., P. MICHEL, M. PARESY, F. LEMOINE, M. F. HELlOT, B. PAIllot, M. SCOTTE, C. PEILLON, J. HEMET (2001): Cell proliferation in colorectal adenocarcinomas: comparison between Ki-67 immunostaining and bromodeoxyuridine uptake detected by immunohistochemistry and flow cytometry. Pathol. Res. Pract. 197, 411-418.

DOI: 10.1078/0344-0338-00054

LI, L. T., G. JIANG, Q. CHEN, J. N. ZHENG (2015): Ki67 is a promising molecular target in the diagnosis of cancer (review). Mol. Med. Rep. 11, 1566-1572.

DOI: 10.3892/mmr.2014.2914

MUSKHELISHVILI, L., J. R. LATENDRESSE, R. L. KODELL, E. B. HENDERSON (2003): Evaluation of cell proliferation in rat tissues with BrdU, PCNA, Ki-67(MIB-5) immunohistochemistry and in situ hybridization for histone mRNA. J. Histochem. Cytochem. 51, 1681-1688.

DOI: $10.1177 / 002215540305101212$

NAKAJIMA, T., K. KAGAWA, T. DEGUCHI, H. KIMURA, M. KAKUSUI, T. KATAGISHI, Y. MITSUMOTO, T. OKANOUE, K. KASHIMA, T. ASHIHARA (1999): Novel formula for cell kinetics in xenograft model of hepatocellular carcinoma using histologically calculable parameters. Exp. Cell Res. 246, 412-420.

DOI: $10.1006 /$ excr.1998.4252

NILSSON, R., M. MICIC, J. FILIPOVIC, A. VALENTA SOBOT, D. DRAKULIC, M. STANOJLOVIC, G. JOKSIC (2016): Inhibition by blueberries (bilberries) and extract from milk thistle of rat forestomach hyperplasia induced by oral smokeless tobacco (Swedish snus). Regul. Toxicol. Pharmacol. 76, 94-101.

DOI: 10.1016/j.yrtph.2016.01.017

POZAROWSKI, P., Z. DARZYNKIEWICZ (2004): Analysis of cell cycle by flow cytometry. Methods Mol. Biol. 281, 301-311.

DOI: 10.1385/1-59259-811-0:301

PROCTOR, D. M., N. M. GATTO, S. J. HONG, K. P. ALLAMNENI (2007): Mode-of-Action framework for evaluating the relevance of rodent forestomach tumors in cancer risk assessment. Toxicol. Sci. 98, 313-326.

DOI: $10.1093 /$ toxsci/kfm075

QIN, J., X. PEI (2018): Isolation of human gastric epithelial cells from gastric surgical tissue and gastric biopsies for primary culture. Methods Mol. Biol. 1817, 115-121.

DOI: 10.1007/978-1-4939-8600-2_12

REICHARD, A., K. ASOSINGH (2019): Best practices for preparing a single cell suspension from solid tissues for flow cytometry. Cytometry A 95, 219-226.

DOI: $10.1002 /$ cyto.a. 23690 
SMITH, C. C., D. J. ADKINS, E. A. MARTIN, M. R. O'DONOVAN (2008): Recommendations for design of the rat comet assay. Mutagenesis 23, 233-240.

DOI: $10.1093 /$ mutage/gen008

SOBECKI, M., K. MROUJ, J. COLINGE, F. GERBE, P. JAY, L. KRASINSKA, V. DULIC, D. FISHER (2017): Cell-Cycle regulation accounts for variability in Ki-67 expression levels. Cancer Res. 77, 2722-2734.

DOI: 10.1158/0008-5472.can-16-0707

TANAKA, R., M. TAINAKA, T. OTA, N. MIZUGUCHI, H. KATO, S. URABE, Y. CHEN, J.-M. FUSTIN, Y. YAMAGUCHI, M. DOI, S. HAMADA, H. OKAMURA (2011): Accurate determination of S-phase fraction in proliferative cells by dual fluorescence and peroxidase immunohistochemistry with 5-bromo-2'-deoxyuridine (BrdU) and Ki67 antibodies. J. Histochem. Cytochem. 59, 791-798.

DOI: $10.1369 / 0022155411411090$

TRAN, L. S., R. L. FERRERO (2018): Isolation of mouse primary gastric epithelial cells to investigate the mechanisms of helicobacter pylori associated disease. Methods Mol. Biol. 1725, 119-126.

DOI: 10.1007/978-1-4939-7568-6_10

UEHARA, T., S. A. ELMORE, K. A. SZABO (2018): Chapter 6 - Esophagus and Stomach. In: Boorman's Pathology of the Rat.(Suttie, A. W., Ed.), Academic Press, Boston, pp. $35-50$.

Received: 4 February 2020

Accepted: 19 May 2020

JOKSIĆ, G., J. FILIPOVIĆ TRIČKOVIĆ, M. MIĆIĆ, I. JOKSIĆ, A. VALENTA ŠOBOT, M. DEMAJO: Optimizacija metode za izolaciju epitelnih stanica iz nežljezdanog dijela želuca štakora za protočnu citometriju. Vet. arhiv 90, 517-525, 2020.

\section{SAŽETAK}

Tradicionalne metode $u$ ispitivanju stanične proliferacije temelje se na imunohistokemijskom otkrivanju proliferacijskih stanica u ciljanom tkivu. Kako su dugotrajne, optimizacija novih i učinkovitijih metoda važna je za velika istraživanja o proliferaciji. U ovom smo radu željeli optimizirati izolaciju epitelnih stanica prednjeg želuca štakora za protočnu citometriju. Kao marker stanične proliferacije koristili smo Ki-67 protutijelo za otkrivanje ovoga nuklearnog proteina izraženog u proliferacijskim stanicama. Također smo učinili imunohistokemijsku detekciju Ki67 pozitivnih stanica i bojenje propidij-jodidom kako bismo potvrdili rezultate. Butil-hidroksianizol korišten je kao pozitivna kontrola da se osigura stanična proliferacija. Rezultati su pokazali da izolacija epitelnih stanica s kolagenazom, tripsinom i staničnim cjedilom osigurava veliku vijabilnost stanica (>95\%) i čistoću uzoraka. Protočna citometrija i Ki-67 bojenje pokazali su da tretman butil-hidroksianizolom dovodi do znakovitog porasta proliferacije. Primijećena je znakovita pozitivna korelacija između rezultata dobivenih imunohistokemijom i protočnom citometrijom, dok su protočni citometrijski podaci imali manju pogrešku mjerenja, što upućuje na jednaku osjetljivost i veću točnost ove metode. Bojenje propidij-jodidom pokazalo je da postotak stanica u G2+S fazi staničnog ciklusa pozitivno korelira s postotkom Ki-67 pozitivnih stanica procijenjenih protočnom citometrijom, što upućuje na to da Ki-67 oslikava stanice u aktivnoj diobi. Zaključujemo da je opisana izolacija epitelnih stanica prednjeg želuca štakora jednostavna i pouzdana metoda za dobivanje održivih stanica za upotrebu u protočnoj citometriji. U usporedbi s imunohistokemijom, protočna citometrijska detekcija antigena Ki-67 jednako je osjetljiva, ali mnogo brža i daje točnije rezultate.

Ključne riječi: Ki-67; izolacija epitelnih stanica; protočna citometrija; nežljezdani želudac štakora; stanična proliferacija 
